\title{
Meet the Spring 2020-21 APSA Minority Fellows
}

\section{T}

he APSA Minority Fellows Program (MFP), established in 1969, is a longstanding fellowship competition to diversify the profession by providing support to students from underrepresented backgrounds applying to, or in the early stages of, a $\mathrm{PhD}$ program in political science. The goal of the program is to increase the number of minority scholars in the discipline, particularly political science $\mathrm{PhD}$ programs, and ultimately the professoriate. APSA has once again awarded a new cycle to provide support for first- and second-year political science $\mathrm{PhD}$ students. Please join us in congratulating this new class of fellows.

\section{Alexia Alkadi-Barbaro}

Alexia Alkadi-Barbaro is a second-year political theory $\mathrm{PhD}$ student in the Depart-

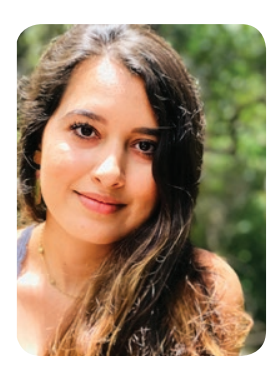
ment of Government at Cornell University. Currently, Alexia's scholarly work focuses broadly on the construction of notions of justice, equality, and beauty in mid-2oth century anticolonial political thought, and how these concepts were shaped by and spoke to the emerging ecological and food crises of the Global South. To this extent, her research draws on a range of scholarly backgrounds in the humanities and social sciences including Indigenous studies, Africana studies and the emerging field of the environmental humanities to consider how visions of anticolonial sovereignty amongst farmers, politicians and activists within the Middle East and North Africa as well as Sub-Saharan Africa were premised on sustainable ecological and agricultural practices in the mid 2oth century. Outside of her research, Alexia is involved with building the Cornell University Freedom School and is an active advocate for equal access to education amongst low-income and minority students.

\section{Anthony Bencomo}

Anthony Bencomo is a Latino PhD student in the Department of Politics at the University of California, Santa Cruz, with a designated emphasis in Latin American and Latino Studies. Raised in Fresno, Califor- nia, his research interests include local politics, Latinx politics, gangs, and political participation. Anthony earned his BA in sociology and Chicano studies from Fresno State and graduated with his MA in Mexican American studies from San José State University. At Fresno State, he became a McNair Scholar, where he examined politi-

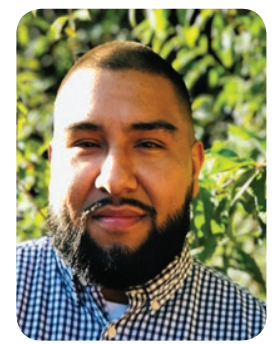
cal participation of former prisoners and United States-Mexico relations in the late 19th century. His current research project seeks to examine the impact of nonstate actors on local politics, specifically in California's San Joaquin Valley. Once earning his doctorate degree, Anthony hopes to become a professor where he will teach courses in American politics, Latinx politics, and the politics of crime.

\section{Olivia Britton}

Olivia Britton is a political science $\mathrm{PhD}$ student and a National Science Foundation Graduate Research Fellow at Boston University. Her work, at the nexus of political economy and human security, examines how states provide services to refugees and the implications of service provision for the daily lives of refugees. She has done extensive fieldwork in Calabria, Italy where she researched and analyzed how neoliberalism has reshaped humanitarian aid efforts and transformed refugee management as a means to economically revitalize abandoned small Italian towns. Prior to coming to Boston University, Olivia graduated with honors from Union College (Schenectady,

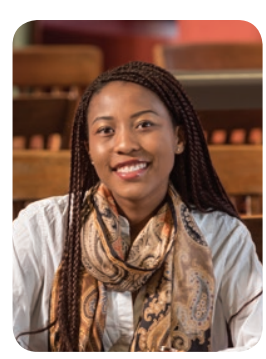
$\mathrm{NY)}$ with a BA in political science and anthropology. There she was awarded the Klemm Fellowship to develop her senior thesis, "New Slaves: The Entrepreneurship of Refugee Lives." After completing her $\mathrm{PhD}$, Olivia wishes to pursue a career as a senior researcher, serving as a liaison between academia, human rights agencies, and policy makers.

\section{Michelle Bueno Vasquez}

Michelle Bueno Vásquez is a political science PhD student at Northwestern University. Michelle graduated from the University of Chicago with special honors in political science, with a focus on studying effects of stereotype threat on Black high school students' political attitudes. As a graduate student, Michelle studies American and comparative politics, with a focus on race and identity formation in AfroLatino communities. Currently, she is researching how transnational information flows

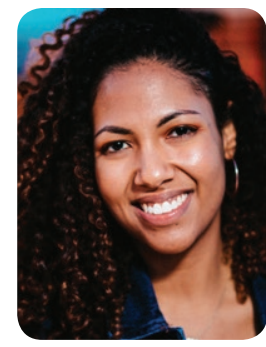
can mutate ideas of race throughout the Dominican diaspora, particularly between the United States and Dominican Republic. She hopes to pursue a dissertation agenda that explores the political and social movement implications of the Afro-Latino identity that exists at the margin in the United States, its impact on Black and Latino coalition building, and how this burgeoning movement spreads and manifests in Latin America.

\section{Maya Camargo-Vemuri}

Maya Camargo-Vemuri is a $\mathrm{PhD}$ candidate at Johns Hopkins University's School of

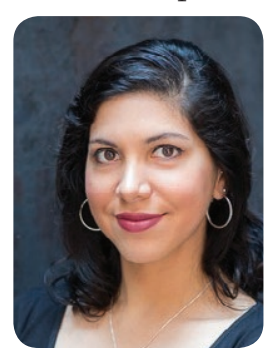
Advanced International Studies. Her research focuses on sexual violence, identity, political trauma, and memory in genocide and mass violence. She is interested in how political trauma is remembered and memorialized, the interplay between violence and identity, and how gender and sexuality impact how violence is experienced. In 2019, she was a Graduate Research Fellow at the US Holocaust Memorial Museum, where she researched sexual violence in Eastern Europe during the Holocaust. Maya graduated from American University with a BA in international affairs and literature. In 2017 , she graduated from the University of Maryland with an MPP, with a dual specialization in International Security and Economic Policy, and Conflict, Justice and Ethics. After graduating, she was a Boren 
Fellow in Senegal, where she studied state corruption and human security in West Africa. Prior to beginning her $\mathrm{PhD}$, she was a visiting researcher in Peru, where she investigated state abuses of human rights and earned a Certificate in Humanitarian Law, Human Rights, and Armed Conflict at the Pontificia Universidad Católica del Perú.

\section{Samantha Canty}

Samantha Canty is a PhD student at the University of California, Irvine in the Department of Political Science. She earned a BA in in economics and political science at the Florida Gulf Coast Univer-

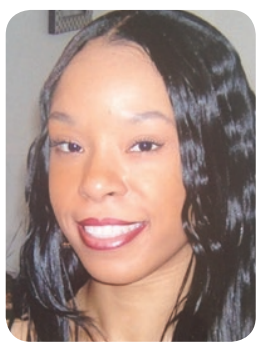
sity. Before returning to pursue her doctorate, she worked in various capacities with underprivileged youth, which inspired her to influence public policy, specifically as it pertains to African Americans. Her research interests are in the field of American politics and race and ethnicity. She is broadly interested in racial attitudes, voting behavior and political inequity in Black communities. She looks forward to developing an innovative research agenda that will have a direct impact on public policy and lawmaking. She is currently researching religious activity and political engagement among African Americans.

\section{Samantha Chapa}

Samantha Chapa is a second-year $\mathrm{PhD}$ student in the Department of Political Science at the University of Houston. She is interested in the intersection between human rights and immigration policy and is currently studying how nationalist waves across the globe affect immigrants' rights, political participation, and policy. She is also examining biases and discrepancies

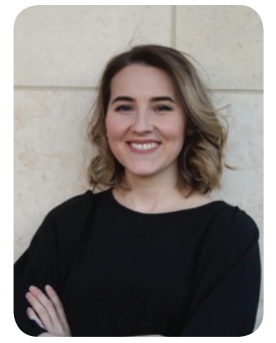
in immigration court outcomes across the United States. While at UH, Samantha has lectured undergraduate students on US immigration policy and served as a TA for human rights courses. Prior to beginning her doctoral studies, Samantha worked as a Department of Justice (DOJ) Accredited Representative at BakerRipley, where she legally represented vulnerable immigrant groups in both affirmative and court proceedings. Her direct experiences with refugees, asylees, and detained immigrants informs her research, and she hopes to continue working with such communities by engaging in research that examines the political participation, representation, and rights of immigrants. Samantha obtained a BA in English and history from Rice University in 2016.

\section{Sonya Chen}

Sonya Chen is a $\mathrm{PhD}$ student in politics and social policy at Princeton University. She received her BA with high honors from Swarthmore College, majoring in political science with minors in sociology and statistics. Her research interests include racial and ethnic politics, migration, and inequality in the United States, as well as diaspora politics. Specifically, she is interested in examining the prospects and challenges of Asian American pan-ethnicity and interracial coalitions. Her current project looks at the politics of affirmative action, the policy's shifting rationale from remedial justice to diversity, and what this means for racial cleavages, coalition politics, and racial

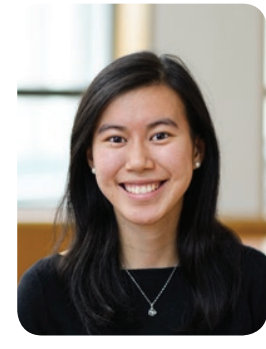
justice. At Princeton, she is involved with the Graduate Women of Color Caucus and co-founded the politics department's Students of Color and Allies organization. After completing her $\mathrm{PhD}$, Sonya hopes to pursue a career in academia. She aspires to practice inclusive and engaging pedagogies in the classroom and to support and mentor students from underrepresented backgrounds. She is passionate about producing academic research that is accessible and committed to naming and addressing inequalities.

\section{Norris Davis III}

Norris Davis III is a first-year PhD student in the Charles and Louise Travers Department of Political Science at the University of California, Berkeley. His research interests include political behavior, race and ethnic politics, and the Black diaspora in

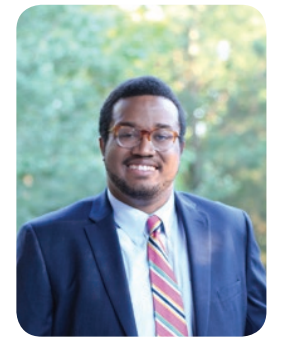

the United States. Specifically, he is interested in the relationship between Black political elites and Black voters, and how it affects mobilization and political participation. Davis graduated from the University of Alabama with a BA in African American studies and political science, summa cum laude. As an undergraduate, he was selected as a University Fellow, conducting research on the Anti-Racism Movement in Cuba and on the efficacy of race-conscious curricula in education systems. He hopes to pursue a career in academia, while actively organizing and promoting inclusion in the field.

\section{Mai Nguyen Do}

Mai Nguyen Do is a first-year PhD student in the Department of Political Science at the University of California, Riverside, where she also works as a researcher for AAPI Data. Her research interests include Southeast Asian refugees in the United States, their resettlement and the development of Southeast Asian refugee communities in the United States, and Asian American politics more broadly. Currently, she is focused on examining ways in which the resettlement of Vietnamese refugees can shed

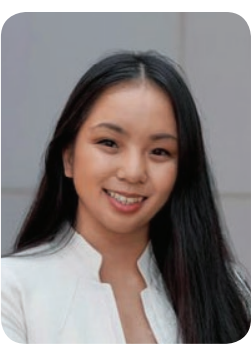
further light on immigrant cohort effects and the development of ethnic community institutions. Prior to coming to UC Riverside, she graduated from College of the Canyons, completed her BA in political science at Washington College, and worked as a research and policy associate at Courage California. As a former Vietnamese language school teacher, she looks forward to furthering her passion for education and continuing to engage in research that the students she serves find useful.

\section{Bianca Freeman}

Bianca Freeman is a second-year PhD student in the Department of Political Science at the University of California, San Diego (UCSD). Her interests are in international relations with a focus on race, law, and military intervention. Bianca's current project examines Status of Forces Agreements and how race shapes the terms of criminal

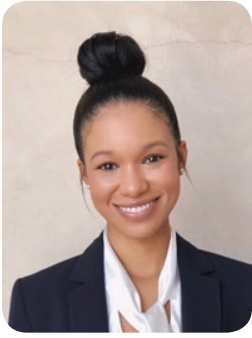


jurisdiction between military partners. In addition, her work analyzes the responsibility to protect and how racial norms interact with international legal principles to influence the decision to intervene in other states. Prior to joining the UCSD community, Bianca worked as an analyst in Washington, DC. She earned her MPP and BA from the University of California, Riverside (UCR). As an undergraduate student, she was elected to Phi Beta Kappa her junior year, received the UCR Political Science Department Outstanding Student Award her senior year, and served her graduating class as Student Speaker of Commencement. Bianca enjoys mentoring and teaching students from diverse backgrounds and desires to make contributions that enrich inclusivity and intellectual life in the discipline.

\section{Tranae Hardy}

Tranae Hardy is a PhD student in the Department of Government at Georgetown

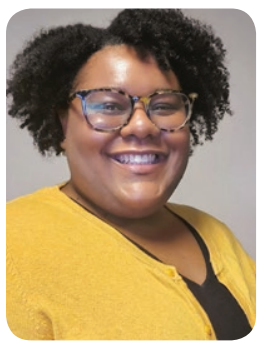

University where she studies American government. Prior to her doctoral studies, she received a $\mathrm{BS}$ in economics from the University of Pennsylvania and a MS in social science from Towson University. Her research interests center on Congress, legislative behavior, and political parties. Currently, she is working on a project that explores the relationship between increased electoral competition and the use of simple resolutions in Congress as messaging tools to emphasize party differences. She is also working on a collaborative project examining the trends in and evolution of the conduct of political science research. Upon completing her doctorate, Tranae will pursue a career in academia.

\section{Allegra Hernandez}

Allegra E. Hernandez is a second year PhD student at Rice University. She works to understand how legacies shape current political settings. She is primarily interested in cultural legacies and the effect that they have on institutions and individual behavior. Allegra's research interests stem from

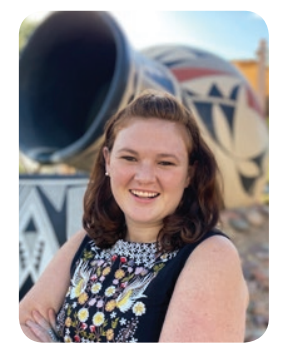

her childhood, where she grew up in the only public school district in the country that busses students from Mexico to the United States every day. The dichotomy between New Mexico's welcoming policies towards Mexico versus Arizona's passage of SB-1070 in 2010, which imposed some of the strictest immigration controls in the country, is something that Allegra noticed, but was never able to fully explain-a fact she hopes to rectify at some point. Her current work examines foreign-imposed communism in Eastern Europe during the Cold War to understand how it shapes contemporary attitudes towards international institutions and multiculturalism. In 2017, Allegra graduated from Texas Christian University with a BS in political science and a BA in art history. As an undergraduate, she worked with the Department of State in Albania, where she organized joint military training exercises, and Zambia, where she focused on policies aimed to alleviate ethnic divides following electoral loss.

\section{Tricia Huynh}

Tricia Huynh is a $\mathrm{PhD}$ student in the Department of Political Science at the University of California, Los Angeles. She is currently studying race and ethnic politics, specifically Asian American politics, under the advisement of Dr. Natalie Masuoka.

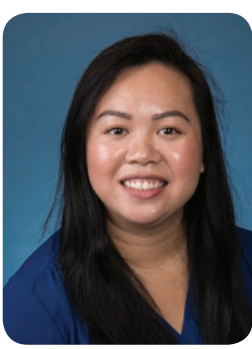
Prior to attending UCLA, Tricia graduated from the University of California, San Diego with a BA in American politics and a minor in communication. Her main research interests include Asian American political behavior, attitudes on immigration policy, and refugee studies. Currently, she is working on a project that studies the effect of memory and trauma on Vietnam War refugees' opinions on immigration policy. As a first-generation college student, Tricia hopes to serve as a mentor to other firstgeneration scholars like her who want to pursue higher education.

\section{Briana Hyman}

Briana Hyman is a second-year political science PhD student at Howard University, majoring in Black politics and American government, with a minor in political theory. Briana leverages her BS in communication and MPA to fuel her research efforts in African American and Latina/o/x political behavior and policy support. She has presented at multiple conferences such as NCOBPS and ArkPSA on subjects including Pan-Africanism, Emerging Self-Iden-

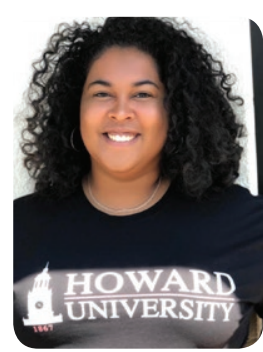
tification of Afro-Latinx Americans, Black Female Mayoral Re-Elections, and Federalism and Slavery as Supported by the Courts. Additionally, Briana was a Woodford R. Porter scholar at the University of Louisville and the recipient of the Hugh T. Henry Memorial Scholarship while attending the University of Arkansas. In pursuing a career in academia, Briana intends to continue her research while focusing on her students' successes-both within and outside of the classroom-with the goal of increasing next generation political awareness within communities of the Diaspora.

\section{Francy Luna Diaz}

Francy Diaz is a first-year student in the political science $\mathrm{PhD}$ program at the University of Michigan. She graduated summa cum laude from the University of Arizona, receiving a BA in political science and a BA in law. She is a Robie Gold Medal Award recipient and the 2019 Honors College Outstanding Senior. Francy is also a Rackham Merit Fellow and an All Arizona

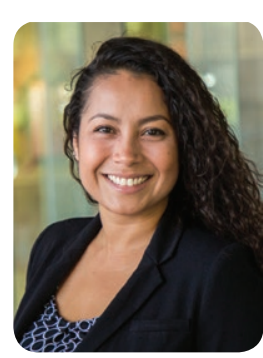
Scholar. Francy also graduated top of the Class of 2016 from Pima Community College. Francy served as the commencement speaker for her graduation ceremony, and thanks to her academic performance, volunteerism, and leadership, she was awarded the All Arizona Tuition Waiver. Francy participated in the Undergraduate Research Consortium Opportunity, and under the mentorship of Professor Samara Klar, she researched the effect of minority representatives on the political participation of Latina constituents. She presented her research at the Emerging Scholars Conference and the UROC poster session and conference. Francy's research interests center around gender, race, and minority representation, especially issues pertaining to Latinos. She is currently working on a project about empathy and support for immigration policy with her UM adviser, 
Nick Valentino. She aspires to become a tenured professor and continue her research about Latinos.

\section{Amber Mackey}

Amber Mackey is a $\mathrm{PhD}$ student at the University of Pennsylvania studying political behavior and public policy. She graduated from Barnard College of Columbia University in 2018 with a double major in political science and sociology. As a Mellon

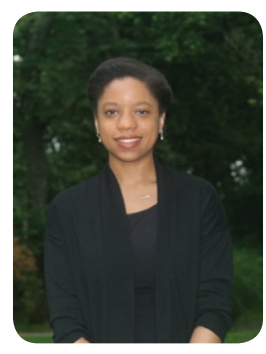

Mays Undergraduate Fellow, her undergraduate research explored social movements, felon disenfranchisement, and pseudo-descriptive representation. She is particularly interested in the attitudes and behaviors of racial minorities that opt-out of more conventional forms of political participation. Amber is currently researching how the political behaviors associated with patriotism vary across space, time, and identities. As an Urban Leaders Fellow in New Orleans and Intern at EMIDA in Cameroon, Amber has partnered with numerous non-profit organizations to gather and analyze data on mass incarceration, protests, and public opinion. In addition to pursuing a career within academia, Amber is dedicated to teaching tools for data collection, analysis, and advocacy work to others within her community.

\section{Bea-Sim Ooi}

Bea-Sim Ooi is a PhD student in the Department of Political Science at the University of California, Riverside, where she is the recipient of the Chancellor's Distinguished Fellowship. Her subfields are mass political behavior and American politics, with an emphasis on class and income inequality, race and ethnic politics, policing, and incarceration. Prior to attending graduate school, she

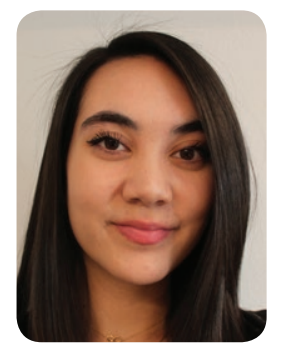
received her BA in political science from the University of California, Riverside, where she served as senior research assistant. Following the completion of her graduate studies, Bea-Sim hopes to pursue a career in academia, while remaining engaged in activism and collective justice.

\section{Judney Pierre}

Judney Pierre is a first year PhD student in the Department of Political Science at the University of California Irvine, where he studies institutions, particularly the executive branch. Judney is a Miami native and two-time alumnus of Florida International University where he obtained both his BA and MA in public administration

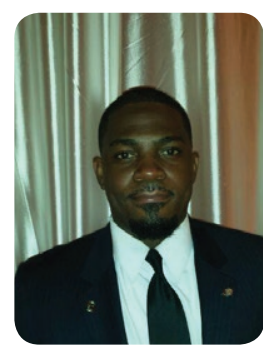
with a specialization in policy implementation and development. Judney has experience in working for non-profit organizations and government agencies such as the US Department of Labor, the Haitian American Youth Task Force and the 50oo Role Models of America. He has also conducted research on electoral races in the 2016 elections for all 50 states while interning for Project Vote Smart. He is the author of "How E-government and Technology Can Lead to Smarter Government in the United States" (Public Administration Times) which reveals the different technological advances presidents could employ to increase responsiveness with other branches.

\section{Chloe Ricks}

Chloe Ricks is a second-year PhD student studying comparative politics at the University of Pennsylvania. Her research interests include comparative race and sub-national politics, with special focus on Latin America and the US South. She completed her undergraduate degree at Duke

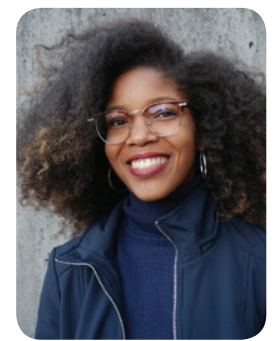
University, where she majored in international comparative studies. Chloe graduated with highest distinction, and won the 2018 ICS Distinguished Thesis Award for her senior honors thesis "'Last Stop Destination': Poverty, Antiblackness and University Education in the Mississippi Delta and Brazil's Baixada Fluminense." Upon completion of her doctoral program, Chloe plans to pursue a career in academia.

\section{Jessica Taghvaiee}

Jessica Taghvaiee is a first-year political science PhD student at the University of California, Irvine. Jessica graduated summa cum laude from Westminster College with a triple major in political science with a pre-law emphasis, Spanish-Latin American studies, and an honors degree. Jessica is also a Gates Millennium Scholar and McNair Scholar.

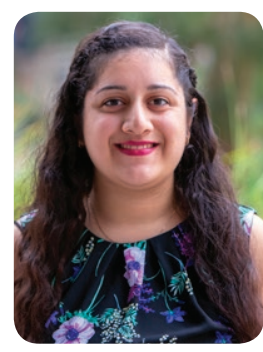
At UCI, Jessica serves as a Diverse Educational Community and Doctoral Experience (DECADE) student representative for her department and one of the leads of the Political Science Womxn's Caucus. She is interested in comparative politics and race, ethnicity, \& politics. As the daughter of an Iranian refugee and a Mexican immigrant, Jessica is passionate about immigration policy research. Presently, she is researching how nation-states like the US and Spain use immigration policy deadlines to control migrants' time and grant or defer them legal status. As a scholar and an activist, Jessica strives to produce valuable innovative and interdisciplinary research that can contribute to fixing not only the US immigration system, but also provide more transnational solutions to a global issue that continues to affect the livelihoods and humanity of thousands of migrants today.

\section{Erika Vallejo}

Erika Vallejo is a political science $\mathrm{PhD}$ student at Michigan State University. She is a RGV native and obtained her BA in political science and philosophy from the University of Texas Rio Grande Valley. Prior to MSU, Erika worked at an educational center where she greatly enjoyed working with students and furthered her passion for academia. Her research interests include American politics, specifically gender, race, class, immigration, and labor relations. Her proposed research

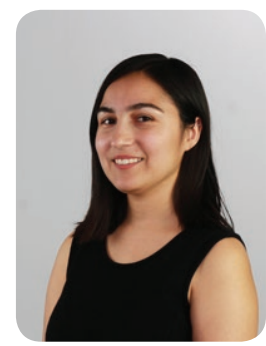
agenda focuses on the lack of working-class candidates and how to motivate them to run for office. After completing her $\mathrm{PhD}$, Erika hopes to pursue a career in academia or in the non-profit sector.

\section{Angel Manuel Villegas Cruz}

Angel M. Villegas-Cruz is a first-year $\mathrm{PhD}$ student at Pennsylvania State University. He is pursuing a dual-title $\mathrm{PhD}$ in political science and Asian studies. His primary 


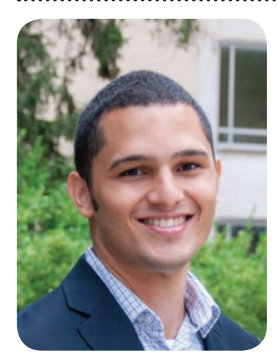

subfield of study is international relations, with a minor in comparative politics. Prior to attending Penn State, Angel received an MA in international relations from Beijing Normal University and a BA in sociology from the University of Puerto Rico, Rio Piedras Campus. His research interests include the political economy of Chinese foreign aid and outward foreign direct investment. Angel looks forward to teaching classes in international relations, international political economy, and Chinese foreign policy. Upon completing the doctorate, Angel will pursue a career in academia.

\section{Marques Zárate}

Marques Zárate is a PhD student in the political science department at Rice University. He graduated cum laude from Seton Hall University in 2018 with a BA in political science. His research examines racial politics and political behavior through the lens of psychology. Marques' current work investigates how external cues, such as threat or political communication, affect the way that people engage with

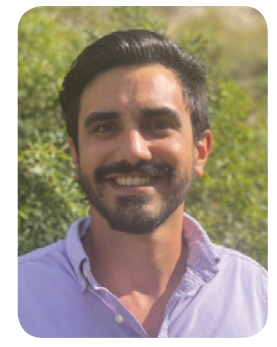
their political environment. His first line of research explores how Latinos in the United States feel when politicians use Spanish language appeals. The second line of research, presented at SPSA 2020, examines whether political trust acts as a moderator for anxiety and political participation. Ultimately, Marques hopes to understand what forces can help drive inclusion in the political process as well as steps we can take to encourage greater participation. 